\title{
Effect of different concentrations of dietary safflower seed on milk yield and some rumen and blood parameters at the end stage of lactation in dairy cows
}

\author{
Mustafa Numan Oguz ${ }^{1}$, Fatma Karakas Oguz ${ }^{1}$, Tulay lleri Buyukoglu ${ }^{2}$ \\ ${ }^{1}$ University of Mehmet Akif Ersoy, Faculty of Veterinary Medicine, Department of Animal Nutrition and Nutritional Diseases, Istiklal Campus, Burdur, \\ Türkiye. \\ ${ }^{2}$ University of Mehmet Akif Ersoy, Faculty of Veterinary Medicine, Department of Biochemistry, Istiklal Campus, Burdur, Türkiye.
}

\begin{abstract}
In this study, the effects of different concentrations of dietary safflower seeds (SS) were examined for milk production, milk fat and some rumen and blood parameters at the end stage of lactation in dairy cows. Four Holstein cows were assigned to a $4 \times 4$ Latin Square design with four stages. All stages had $14 \mathrm{~d}$ of adaptation and $7 \mathrm{~d}$ of data collection periods. The diets were formulated as isoenergetic and isonitrogenous. Cows were fed four concentrate mixtures containing $0 \%$ (Control; C), 12.5\% (S-I), 25\% (S-II), or 37.5\% (S-III) crushed SS during the experimental period. Safflower seed intake was distributed as 0 (C), 1 (S-I), 2 (S-II) and 3 (S-III) kg/d/cow. Cows were fed $8 \mathrm{~kg}$ concentrate, $2 \mathrm{~kg}$ wheat straw, and corn silage ad libitum (approximately $20 \mathrm{~kg}$ ). Diet S-III caused a decrease in efficiency of milk production and diet S-II provided a much further efficiency in milk production $(\mathrm{C}=13.39 \pm 0.23, \mathrm{~S}-\mathrm{I}=12.94 \pm 0.26, \mathrm{~S}-\mathrm{II}=13.46 \pm 0.24$ and S-III $=11.83 \pm 0.52 \mathrm{~kg})$. Diets had no significant effect on milk fat $(\mathrm{C}=3.99 \pm 0.18$, S-I $=4.09 \pm 0.16$, S-II $=3.87 \pm 0.35$ and S-III $=3.75 \pm 0.30 \%)$. There was no difference in rumen fluid and blood parameters. Short-time feeding of up to $2 \mathrm{~kg} / \mathrm{d}$ safflower seed had no negative effects on milk yield, milk fat, and some serum parameters, but $3 \mathrm{~kg} / \mathrm{d}$ safflower seed reduced milk production. Safflower seed can be safely fed at up to two kilograms daily at the end stage of lactation in dairy cows.
\end{abstract}

Key Words: milk, oilseed, rumen parameter

\section{Introduction}

The Asteraceae family is the largest family of vascular plants and includes many commercially important species like sunflower, safflower, globe artichoke, Jerusalem artichoke and yacon. The safflower plant is $0.6-1.5 \mathrm{~m}$ high and produces many branches with heads at the ends. Each head, as in other thistles, consists of numerous flowers; each normally produces a single seed. A head may produce 20-100 small seeds like sunflower seed (FAO, 2004).

The safflower seed (SS) contains about $12-17 \%$ crude protein, $25-40 \%$ ether extract and $20-33 \%$ crude fiber. The nutrient composition of SS changes depending on region, soil and variety. Safflower oil is also rich in polyunsaturated fatty acids (78\% linoleic acid), which play an important role on reducing the level of blood cholesterol. Uysal et al. (2006) reported that safflower (Carthamus tinctorius L.)

Received June 21, 2013 and accepted January 21, 2014

Corresponding author: mnoguz@mehmetakif.edu.tr

http://dx.doi.org/10.1590/S1516-35982014000400007

Copyright (C) 2014 Sociedade Brasileira de Zootecnia. This is an Open Access article distributed under the terms of the Creative Commons Attribution Non-Commercial License, which permits unrestricted non-commercial use, distribution, and reproduction in any medium, provided the original work is properly cited. had been traditionally grown for vegetable oil production in Isparta, Turkey; the seed oil of most of Safflower lines is rich in linoleic acid and poor in oleic acid in Turkey and the total tocopherol content of safflower oils is between 131.6 and $163.2 \mathrm{mg} / 100 \mathrm{~g}$. After safflower seed is used for extraction of the oil, its by-product, safflower cake, is used as animal feed.

In safflower seed and seed cake, the methionine and isoleucine contents are hardly adequate, but lysine is quite limited (Nimbkar, 2010). Ivan et al. (2004) reported that the use of sunflower seed supplementation in high-concentrate diets for ruminants reduces the rumen fauna.

Yuk et al. (2002) found that safflower seed extract is effective for the treatment of diseases such as osteoporosis and bone resorption. It is well known that dietary phospholipids lower serum cholesterol levels effectively and crude safflower phospholipids can be used as a feed ingredient to reduce the fatty liver syndrome in laying hens (An et al., 1997). Bell et al. (2006) reported that additional safflower oil at $60 \mathrm{~g} / \mathrm{kg}$ DM in the feed increased the conjugated linoleic acid (CLA) content in cow milk. The anti-carcinogenic effects of CLA have been widely accepted and the best natural source of CLA is ruminant milk (Dschaak et al., 2010). 
The objective of this experiment was to determine the effects of diets containing $0,1,2$ and $3 \mathrm{~kg} / \mathrm{d} \mathrm{SS}$ on milk yield, milk fat and some blood and rumen parameters of dairy cows.

\section{Material and Methods}

Four Holstein cows with approximately same milk production and body weight, at the end stage of lactation periods on a private farm were used in the experiment. Cows had $13 \pm 0.7 \mathrm{~kg}$ milk production, $500 \pm 18 \mathrm{~kg}$ live weight and were at the $272 \pm 12 \mathrm{~d}$ of 3 rd lactation. The animals were housed on a farm and assigned to a $4 \times 4$ Latin square design with four periods. Each experimental period lasted $21 \mathrm{~d}$ (14 d for dietary adjustment and $7 \mathrm{~d}$ for data collection).

The diets were formulated as isoenergetic and isonitrogenous (Table 1). Cows were fed four concentrate mixtures containing $0 \%(\mathrm{Control}=\mathrm{C}), 12.5 \%(\mathrm{~S}-\mathrm{I}), 25 \%$ (S-II), or 37.5\% (S-III) crushed SS during the experimental period. Safflower seed intake was arranged as $0(\mathrm{C})$, 1 (S-I), 2 (S-II) and 3 (S-III) kg/d/cow. Cows were fed $8 \mathrm{~kg}$ concentrate $(4 \mathrm{~kg}$ for the morning feeding and $4 \mathrm{~kg}$ for the afternoon feeding), $2 \mathrm{~kg}$ wheat straw (morning feeding) and corn silage (afternoon feeding) ad libitum

Table 1 - Composition of the concentrate mixtures and nutrients (DM basis)

\begin{tabular}{lcccc}
\hline & \multicolumn{3}{c}{ Diets } \\
\cline { 2 - 5 } Ingredients $(\mathrm{g} / \mathrm{kg})$ & Control & S-I & S-II & S-III \\
\hline Barley & 350 & 210 & 110 & 50 \\
Wheat & 124 & 166 & 180 & 220 \\
Wheat bran & 60 & 60 & 44 & 10 \\
Sunflower meal & 200 & 200 & 200 & 150 \\
Safflower seed & 0 & 125 & 250 & 375 \\
Cottonseed meal & 170 & 144 & 100 & 52 \\
Soybean meal & 61 & 60 & 81 & 108 \\
Dicalcium phosphate & 1 & 1 & 1 & 1 \\
Limestone & 25 & 25 & 25 & 25 \\
Salt & 5 & 5 & 5 & 5 \\
Mineral mixture & 2 & 2 & 2 & 2 \\
Vitamin mixture & 2 & 2 & 2 & 2 \\
Analyzed values on DM basis $(\mathrm{g} / \mathrm{kg})$ & & & \\
Dry matter & 887.6 & 897.3 & 902.6 & 904.2 \\
Crude protein & 188.2 & 187.8 & 186.5 & 188.9 \\
Ether extract $_{\text {Ash }}$ & 30.7 & 64.4 & 108.6 & 134.7 \\
Acid detergent fiber & 90.1 & 88.6 & 82.8 & 87.6 \\
Neutral detergent fiber & 352.6 & 178.2 & 196.7 & 215.2 \\
ME $^{3}$ (Mj/kg) & 9.96 & 9.92 & 10.01 & 9.92 \\
\hline Per kg of mineral prem & 2.9 & 429.0 & 442.1 \\
\hline
\end{tabular}

${ }^{1}$ Per kg of mineral premix: Mn - 50,000 mg; Zn - 50,000 mg; Fe - 50,000 mg; $\mathrm{Cu}-10,000 \mathrm{mg}$; I - $800 \mathrm{mg}$; Co - $150 \mathrm{mg}$; Se - $150 \mathrm{mg}$.

${ }^{2}$ Per kg vitamin premix: vitamin A - 15,000,000 IU; vitamin D3 - 3,000,000 IU; vitamin E - 30,000 mg.

${ }^{3}$ Metabolizable energy, calculated from diet software. (approximately $20 \mathrm{~kg}$ ). No concentrate and straw refusals were observed. The animals had free access to water.

Cows were milked twice a day, at $07.00 \mathrm{~h}$ and $16.30 \mathrm{~h}$. Milk yield was recorded during data collection period (7 d) in both morning and afternoon milkings. Blood and rumen fluid samples were collected two hours after the morning feeding on the fourth day of each data collection period $(7 \mathrm{~d})$. Rumen fluid samples were collected via a stomach tube. Blood samples were collected from the vena jugularis with a Vacutainer needle. Serum urea levels (with a commercial kit), serum beta-carotene and vitamin A (Suzuki and Katoh, 1990) and plasma vitamin E levels (Baker and Frank, 1968) were determined using a spectrophotometer (Shimatzu UV1200).

Milk fat levels were determined by the Gerber Method (Marshall, 1992). Feeds were analyzed according to the AOAC (1984), Van Soest (1963) and Crampton and Maynard (1938). Rumen total volatile fatty acids (TVFA) and $\mathrm{NH}_{3}-\mathrm{N}$ were measured according to Markham (1942). Rumen fluid $\mathrm{pH}$ was measured using a $\mathrm{pH}$ meter (Metrohm744).

Data were analyzed using the Kruskal-Wallis test and one-way ANOVA and differences between means were tested by Duncan's test (Zar, 1996).

\section{Results}

In the current study, safflower seed, wheat straw and corn silage samples contained $12.16,3.19$ and $8.13 \%$ crude protein, 32.76, 1.68 and 3.11\% ether extract, $19.83,43.7$ and $24.61 \%$ crude fiber, 32.52, 59.11 and $31.21 \%$ acid detergent fiber (ADF) and 44.20, 81.18 and 52.08\% neutral detergent fiber (NDF), respectively.

Total safflower seed in the diet was adjusted to be 0 (control), 1 (S-I), 2 (S-II), 3 (S-III) kg/d of intake. A significant reduction in milk yield (Table 2) was observed $(\mathrm{C}=13.39 \pm 0.23, \mathrm{~S}-\mathrm{I}=12.94 \pm 0.26$, S-II $=$ $13.46 \pm 0.24$ and S-III $=11.83 \pm 0.52 \mathrm{~kg} / \mathrm{d})$ in the S-III group ( $\mathrm{P}<0.01)$. The highest milk yield was obtained by the S-II group, but statistically similar to the $\mathrm{C}$ group. Diets had no significant effect on the percentage of milk fat $(\mathrm{C}=3.99 \pm 0.18, \mathrm{~S}-\mathrm{I}=4.09 \pm 0.16, \mathrm{~S}-\mathrm{II}=3.87 \pm 0.35$ and $\mathrm{S}-\mathrm{III}=3.75 \pm 0.30)$.

The effects of SS on rumen TVFA, ammonia and ruminal $\mathrm{pH}$, blood serum beta carotene, vitamin $\mathrm{A}$, serum urea and plasma vitamin $\mathrm{E}$ in dairy cows were not statistically different among groups (Table 3 ). 
Table 2 - Average milk yields and milk fat

\begin{tabular}{lccccc}
\hline & \multicolumn{4}{c}{ Groups } & P-value \\
\cline { 2 - 5 } & $\mathrm{C}$ & S-I & S-II & S-III & $* *$ \\
Milk yield $(\mathrm{kg} / \mathrm{d})$ & $13.39 \mathrm{~b} \pm 0.23$ & $12.94 \mathrm{ab} \pm 0.26$ & $13.46 \mathrm{~b} \pm 0.24$ & $11.83 \mathrm{a} \pm 0.52$ & NS \\
Milk fat $(\%)$ & $3.99 \pm 0.18$ & $4.09 \pm 0.16$ & $3.87 \pm 0.35$ & $3.75 \pm 0.30$ & $*$ \\
\hline
\end{tabular}

**a,b, means followed by different letters in the same row differ $(\mathrm{P}<0.01)$.

NS - not significant.

$\mathrm{n}: 16$.

Table 3 - Effect of safflower seed on rumen TVFA, ammonia and ruminal $\mathrm{pH}$, serum beta-carotene, vitamin A, serum urea and plasma vitamin $\mathrm{E}$ in dairy cows

\begin{tabular}{|c|c|c|c|c|c|}
\hline & \multicolumn{4}{|c|}{ Groups } & \multirow{2}{*}{ P-value } \\
\hline & $\mathrm{C}$ & S-I & S-II & S-III & \\
\hline Serum $\beta$-carotene $(\mu \mathrm{mol} / \mathrm{L})$ & $0.95 \pm 0.18$ & $1.00 \pm 0.25$ & $1.16 \pm 0.42$ & $1.19 \pm 0.41$ & NS \\
\hline Serum vit. A $(\mu \mathrm{mol} / \mathrm{L})$ & $0.87 \pm 0.12$ & $1.01 \pm 0.12$ & $1.24 \pm 0.20$ & $1.26 \pm 0.34$ & NS \\
\hline Plasma vit. E $(\mu \mathrm{mol} / \mathrm{L})$ & $117.76 \pm 19.09$ & $128.34 \pm 9.89$ & $142.14 \pm 14.03$ & $146.65 \pm 14.03$ & NS \\
\hline Serum urea $(\mathrm{mmol} / \mathrm{L})$ & $12.83 \pm 1.13$ & $13.96 \pm 0.94$ & $15.32 \pm 0.80$ & $14.54 \pm 1.34$ & NS \\
\hline Rumen TVFA (mmol/L) & $133.75 \pm 8.94$ & $108.00 \pm 8.84$ & $114.50 \pm 8.44$ & $119.88 \pm 8.13$ & NS \\
\hline Rumen ammonia $(\mathrm{mmol} / \mathrm{L})$ & $8.85 \pm 1.14$ & $10.52 \pm 3.75$ & $12.19 \pm 1.51$ & $15.79 \pm 1.44$ & NS \\
\hline Rumen $\mathrm{pH}$ & $5.85 \pm 0.24$ & $6.25 \pm 0.24$ & $6.21 \pm 0.30$ & $6.14 \pm 0.23$ & NS \\
\hline
\end{tabular}

NS - not significant.

$\mathrm{n}: 16$.

\section{Discussion}

With the increased quantity of safflower seed in the diet, the fat content in the diet also increased. The fat (ether extract) contents of concentrates were 3.07, 6.44, $10.86,13.47 \%$ for treatments control, S-I, S-II and S-III, respectively.

Markus et al. (1996) replaced a part of the dry matter of a diet fed to dairy cows by whole sunflower seed and tallow in their experiment, in which three diets were evaluated in relation to a barley-based diet. To provide the same amount of oil in the basal diet, $2.7 \%$ tallow and $7.1 \%$ whole sunflower seed (experimental diets) were added. The milk yields of the groups were 34.4, 34.6 , and $35.5 \mathrm{~kg} / \mathrm{d}$ respectively, and were not influenced by diet. They also reported that inclusion of whole sunflower seeds as a source of fat leads to a similar result to productions of cows fed traditional diets. Petit (2003) investigated the effects of feeding formaldehyde-treated flaxseed or sunflower seed on digestion, milk production, milk composition, and blood composition of dairy cows. They reported that untreated whole flaxseed was readily accepted by dairy cows and had no negative effect on milk production. Moreover, feeding up to $30 \%$ of sunflower seed in the dry matter (DM) had no effect on milk production. These findings were contradictory to the findings of our research. In our experiment, intake of $3 \mathrm{~kg}$ safflower per day decreased milk production. Milk production decreased in the S-III group compared with the control group. All other groups had statistically similar milk yield. The S-II group produced more milk than other groups but it was not statistically significant.

Bottger et al. (2002) determined the effects of supplemental safflower seeds high in linoleic or oleic acid on cow BW change, body condition score, milk production, milk composition and some serum metabolites. Safflower seed supplements were formulated to provide $5 \%$ of DMI as fat. Milk fat was not different at $\mathrm{d}$ 30; however, at $\mathrm{d}$ 60 and $\mathrm{d} 90$, milk fat was greater $(\mathrm{P}<0.05)$ in control and oleate-supplemented cows than linoleat-supplemented cows. Oleate supplementation increased milk fat at $\mathrm{d}$ 60. But contrarily to this finding, in the present study, milk fat level was not affected by dietary safflower supplementation. This may be because the duration of the lactation period (d 270+) is different and the safflower seed produced in Turkey are usually linoleic acid-rich varieties. Godfrey and Dhiman (2006) and Dschaak (2009) reported that the optimum level to feed safflower seed must be identified when it is fed as a whole seed. Similar to these findings, too much safflower seed supplementation in lactating dairy diets had negative impacts on lactation performance in our study.

Generally, the recommended amount of fat intake increases the level of milk fat. However, Magdus et al. (1988) stressed that the physical form of oil is more important than the amount. Saturated, stabilized or protected fats are more efficient. Moreover, the feeding of unsaturated fats or large quantities of fat decreased the milk fat level. Nevertheless, Grummer (1991) reported that feeding free oil depressed 
Table 4 - Phenotypic correlation coefficients among some blood and rumen parameters (rp)

\begin{tabular}{|c|c|c|c|c|c|c|c|}
\hline Parameter & & Vitamin A & Vitamin E & Serum urea & TVFA & Rumen ammonia & Rumen $\mathrm{pH}$ \\
\hline Beta carotene & $\begin{array}{c}\text { Pearson correlation } \\
\text { P-value }\end{array}$ & $\begin{array}{l}0.609^{*} \\
0.012\end{array}$ & $\begin{array}{l}0.574^{*} \\
0.020\end{array}$ & $\begin{array}{r}-0.275 \\
0.303\end{array}$ & $\begin{array}{c}-0.593 * \\
0.016\end{array}$ & $\begin{array}{r}-0.024 \\
0.931\end{array}$ & $\begin{array}{l}0.653 * * \\
0.006\end{array}$ \\
\hline Vitamin A & $\begin{array}{c}\text { Pearson correlation } \\
\text { P-value }\end{array}$ & & $\begin{array}{l}0.442 \\
0.087\end{array}$ & $\begin{array}{r}-0.173 \\
0.522\end{array}$ & $\begin{array}{r}-0.412 \\
0.113\end{array}$ & $\begin{array}{l}0.446 \\
0.083\end{array}$ & $\begin{array}{l}0.528^{*} \\
0.036\end{array}$ \\
\hline Vitamin E & $\begin{array}{c}\text { Pearson correlation } \\
\text { P-value }\end{array}$ & & & $\begin{array}{l}0.128 \\
0.637\end{array}$ & $\begin{array}{r}-0.195 \\
0.470\end{array}$ & $\begin{array}{l}0.180 \\
0.504\end{array}$ & $\begin{array}{l}0.048 \\
0.859\end{array}$ \\
\hline Serum urea & $\begin{array}{c}\text { Pearson correlation } \\
\text { P-value }\end{array}$ & & & & $\begin{array}{l}0.042 \\
0.877\end{array}$ & $\begin{array}{l}0.311 \\
0.241\end{array}$ & $\begin{array}{r}-0.199 \\
0.461\end{array}$ \\
\hline TVFA & $\begin{array}{c}\text { Pearson correlation } \\
\text { P-value }\end{array}$ & & & & & $\begin{array}{l}-067 \\
0.807\end{array}$ & $\begin{array}{l}-0.900 * * \\
0.000\end{array}$ \\
\hline Rumen ammonia & $\begin{array}{c}\text { Pearson correlation } \\
\text { P-value }\end{array}$ & & & & & & $\begin{array}{l}0.020 \\
0.941\end{array}$ \\
\hline
\end{tabular}

n: $16, * \mathrm{P}<0.05, * * \mathrm{P}<0.01$.

milk fat yield, but feeding oil as part of oilseeds did not change the milk-fat yield. In the present study, diets had no significant effect on milk fat, therefore milk fat tended to decrease in cows with increasing SS supplementation. This may be associated with the higher level of fat in the experimental diets compared with control diet.

Blood and rumen parameters of all treatment groups were statistically similar. However, there was an upward trend in beta-carotene, vitamin $\mathrm{A}$ and $\mathrm{E}$ levels when the amount of the SS increased in the diet. This may be related to the oil level in the diets. Fat in the diets helps the absorption of fat-soluble vitamins. The reason for this may be because the cows in our study were fed high-quality corn silage possibly with beta-carotene and tocopherol. Interaction between SS oil and vitamin levels may explain the non-linear increase.

The concentrations of rumen ammonia tended to increase, but this difference was not statistically significant. Hino et al. (1993) reported that addition of safflower oil to a growth medium of in vitro rumen bacteria culture depressed the bacterial growth above $200 \mathrm{mg} / \mathrm{L}$. They also reported that addition of beta-carotene and tocopherol to the medium increased bacterial growth. Ammonia in the rumen is used by bacteria for microbial protein synthesis. If the bacterial population decreases, the usage of ammonia is reduced. In the current study, linoleic acid in the SS may have reduced the bacterial population in the rumen.

The results indicated that serum beta carotene was highly correlated with vitamin $\mathrm{A}$, vitamin $\mathrm{E}$, TVFA $(\mathrm{P}<0.05)$ and rumen $\mathrm{pH}(\mathrm{P}<0.01)$. Serum vitamin $\mathrm{A}$ highly correlated with rumen $\mathrm{pH}(\mathrm{P}<0.05)$. This finding can be related to the oil contents of safflower seed. Fat-soluble vitamins from concentrate diets and corn silage may more effectively absorb in SS groups than those in control group (Table 4).
The study of Dschaak et al. (2010) clearly demonstrated that it was highly possible to use Nutrasaff safflower seed as a means of fat supplementation to lactating dairy cows without negative impact on lactation performance, if added at less than $3 \%$ of dietary dry matter. However, our study yielded results showing that there is a negative effect in group SIII. Far more dietary safflower seed was used (approximately $20 \%$ of the dietary dry matter of group SIII is safflower seed) in this study. This negative effect stemmed from the excessive amount of fat supplied.

\section{Conclusions}

Short-time feeding of of up to $2 \mathrm{~kg} / \mathrm{d}$ safflower seed has no negative effects on the milk yield, milk fat, and some serum parameters, but $3 \mathrm{~kg}$ reduces milk production. Safflower seed can be fed safely at the end stage of lactation in dairy cows at up to two kilogram daily. Further studies may be needed to determine whether high concentrations of safflower seed can be fed safely for longer periods.

\section{Acknowledgments}

The authors thank The Burdur Governorship for financial support, and Burdur Agriculture Province Directorate General, The Scientific Research Council of Akdeniz University, Burdur Veterinary Faculty, and farm owner Arif Koca.

\section{References}

An, B. K.; Nishiyama, H.; Tanaka, K.; Ohtani, S.; Iwata, T.; Tsutsumi, K. and Kasai, M. 1997. Dietary safflower phospholipid reduces liver lipids in laying hens. Poultry Science 76:689-695. 
AOAC - Association of Official Analytical Chemists. 1984. Official methods of analysis of the Association of Official Analytical Chemist. 14th ed. Arlington, VA.

Baker, H. and Frank, O. 1968. Vitamin E. p.169-177. In: Clinical vitaminology. Methods and interpretation. Wiley, New York.

Bell, J. A.; Griinari, J. M. and Kennelly, J. J. 2006. Effect of safflower oil, flaxseed oil, monensin, and vitamin $\mathrm{E}$ on concentration of conjugated linoleic acid in bovine milk fat. Journal of Dairy Science 89:733-748.

Bottger, J. D.; Hess, B. W.; Alexander, B. M.; Hixon, D. L.; Woodard, L. F.; Funston, R. N.; Hallford, D. M. and Moss, G. E. 2002. Effects of supplementation with high linoleic or oleic cracked safflower seeds on postpartum reproduction and calf performance of primiparous beef heifers. Journal of Animal Science 80:2023-2030.

Crampton, E. W. and Maynard, L. 1938. The relation of cellulose and lignin content to nutritive value of animal feeds. Journal Nutrition 15:383-395.

Dschaak, C. M.; Eun, J. S.; Young, A. J. and Bergman, J. J. W. 2010. Nutritive merits of whole Nutrasaff safflower seed when fed to Holstein dairy cows during midlactation. Animal Feed Science and Technology 156:26-36.

Dschaak, C. M. 2009. Production performance and profiles of milk fatty acids of lactating dairy cows fed whole safflower seed containing high fat and low fiber. M.S. Thesis. Utah State University, Utah.

FAO. [2004]. Carthamus tinctorius, safflower, false saffron. Available at: <http://www.fao.org/nr/water/cropinfo_safflower.html $>$ Accessed on: May 14, 2008.

Godfrey, L. R. and Dhiman, T. R. 2006. Influence of method of processing and feeding level of safflower seeds on the performance of dairy cows. Journal of Dairy Science 89(suppl.1):62.

Grummer, R. R. 1991. Effect of feed on the composition of milk fat. Journal of Dairy Science 74:3244-3257.

Hino, T.; Andoh, N. and Ohgi, H. 1993. Effects of beta carotene and alfa tocopherol on rumen bacteria in the utilisation of long chain fatty acids and cellulose. Journal of Dairy Science 76:600-605.

Ivan, M.; Mir, P. S.; Mir, Z.; Entz, T.; He, M. L. and McAllister, T. A. 2004. Effects of dietary sunflower seeds on rumen protozoa and growth of lambs. British Journal of Nutrition 92:303-310.
Magdus, M.; Fekete, G. S.; Frenyó, L. V.; Miskucza, O. and Kotz, L. 1988. Milk production and certain parameters of energy metabolism in dairy cows fed rations of varying energy and crude protein contents and fat. Acta Veterinaria Hungarica 36:43-59.

Markham, R. 1942. A steam distillation apparatus suitable for microkjeldahl analysis. Biochemistry Journal 36:790-791.

Markus, S. B.; Wittenberg, K. M.; Ingalls, J. R. and Undi, M. 1996. Production responses by early lactation cows to whole sunflower seed or tallow supplementation of a diet based on barley. Journal of Dairy Science 79:1817-1825.

Marshall, R. T. 1992. Standard method for the examination of dairy products. 14th ed. p.437-440. APHA, Washington, DC.

Nimbkar, N. 2010. Safflower improvement programme. Nari, India. Available at: <http://nariphaltan.virtualave.net/safflower.htm>. Accessed on: May 14, 2010.

Petit, H. V. 2003. Digestion, milk production, milk composition, and blood composition of dairy cows fed formaldehyde treated flaxseed or sunflower seed. Journal of Dairy Science 86:2637-2646.

Suzuki, J. P. and Katoh, N. A. 1990. A simple and cheap method for measuring serum vitamin A in cattle using only spectrophotometer. Japan Journal of Veterinary Science 52:1281-1283.

Uysal, N.; Baydar, H. and Erbas, S. 2006. Isparta populasyonundan gelistirilen aspir (Carthamus tinctorius) hatlarının tarımsal ve teknolojik özelliklerinin belirlenmesi. SDÜ Ziraat Fakültesi Dergisi 1:52-63.

Van Soest, P. J. 1963. Use of detergent in the analysis of fibrous feed. II: A rapid method for the determination of fiber and lignin. Journal of Association of Official Analitical Chemist 46:829-835.

Yuk, T. H.; Kang, J. H.; Lee, S. R.; Yuk, S. W.; Lee, K. G.; Song, B. Y.; Kim, C. H.; Kim, D. W.; Dong, I. K.; Lee, T. K. and Lee, C. H. 2002. Inhibitory effect of Carthamus tinctorius $\mathrm{L}$. seed extracts on bone resorption mediated by tyrosine kinase, COX-2 (cyclooxygenase) and PG (prostaglandin) E2. American Journal of Chinese Medicine 30:95-108.

Zar, J. H. 1996. Biostatistical analysis. 3rd ed. Prentice-Hall International, Simon and Schuster/Aviacom Company, Upper Saddle River, N.J., USA. 